\title{
Monitoring and Environmental Assessment of Seawater in West Central Africa: Case of the Kribi Industrial and Urban Port Complex in Cameroon, Guinea Gulf
}

\author{
Mioumnde Arthur Paterne1,2*, Kusi Micheline Michelle-Alexia Ngum', Kag Simon Pierre ${ }^{3}$, \\ Kue Petou Rokis Malquaire ${ }^{4,5 *}$, Mumbfu Ernestine Mimba1, Botny-Capel Anne-Eunice1, \\ Dissombo Edimo André Noel ${ }^{1}$, Masso Kody Christelle ${ }^{6}$, Zebaze Jiofack Kevine ${ }^{7}$, Bessong Moise ${ }^{1}$ \\ ${ }^{1}$ Institute of Geological and Mining Research, Yaoundé, Cameroon \\ ${ }^{2}$ Key Laboratory of Deep Oil and Gas (China University of Petroleum (East China)), Qingdao, China \\ ${ }^{3}$ Department of Earth Sciences, University of Yaoundé I, Yaoundé, Cameroon \\ ${ }^{4}$ National Institute of Cartography, Yaoundé, Cameroon \\ ${ }^{5}$ Postgraduate School of Sciences, Technologies \& Geosciences, University of Yaoundé I, Yaoundé, Cameroon \\ ${ }^{6}$ Key Laboratory of Integrated Regulation and Resource Development on Shallow Lakes, Hohai University, Nanjing, China \\ ${ }^{7}$ Department of Environmental and Natural Resources Protection Law, Ocean University of China, Qingdao, China \\ Email: *arthurmioumnde@yahoo.fr, *rokis.petou@yahoo.fr
}

How to cite this paper: Paterne, M. A., Ngum, K. M. M.-A., Pierre, K. S., Malquaire, K. P. R., Mimba, M. E., Anne-Eunice, B.-C., Noel, D. E. A., Christelle, M. K., Kevine, Z. J., \& Moise, B. (2021). Monitoring and Environmental Assessment of Seawater in West Central Africa: Case of the Kribi Industrial and Urban Port Complex in Cameroon, Guinea Gulf. Journal of Geoscience and Environment Protection, 9, 167-183.

https://doi.org/10.4236/gep.2021.96010

Received: February 22, 2021

Accepted: June 26, 2021

Published: June 29, 2021

Copyright $\odot 2021$ by author(s) and Scientific Research Publishing Inc. This work is licensed under the Creative Commons Attribution International License (CC BY 4.0).

http://creativecommons.org/licenses/by/4.0/

\begin{abstract}
This study is the first of a series of a project on the development and implementation of environmental protection policies, before, during and after the construction of the Kribi Industrial and Urban Port Complex (KIPC). The results will equip the State and scientific structures concerned with the protection of people, water resources and the environment as a whole. This includes reference data on the state of marine pollution in the region dating from the end of realization of the first phase of KIPC known as Kribi Deep-Water Harbor (KDWH). Accordingly, the aim of this work is to assess the current state of KIPC and its surrounding by quantifying the preliminary parameters of suspended matter (SM); to analyze the physical and chemical parameters, chemical pollution indicators for anions and major cations and organic pollution indicators of four water samples taken from four different sites in the project area by filtration and weighing, $\mathrm{pH}$ meter, turbid meter, titration, colorimetry and titrimetric methods. The analysis of these samples and these parameters provides results which are slightly similar to international standards. This suggests that the environment remains relatively healthy. Hence, continuous management and monitoring of the parameters and pollution factors is strongly recommended.
\end{abstract}




\section{Keywords}

Kribi Industrial Port Complex, Seawater, Monitoring and Environmental Assessment

\section{Introduction}

In the annals of the United Nations Conference on Trade and Development (UNCTAD) records in 2017, seaborne trade volumes were estimated to exceed 10.6 trillion tons, with growth of more than 2.5 percent. On a global scale, it has a value of more than 1000 billion dollars a year. In West and Central Africa and specifically in the Gulf of Guinea, an emerging market now exists for a regional transshipment compared to the early nineties when the World Bank depicted a low attraction for economic investments. It is widely considered as one of the most dynamic regions in sub-Saharan Africa in the global energy sector and is of critical importance for the economic development of the Atlantic Coast of Africa (Jenkins \& Edwards, 2006). These countries enjoy a wide geological, geographical and cultural diversity. They range from English to French, Portuguese, and Spanish-speaking nations. Overall, the Gulf of Guinea's gross domestic product (GDP) is $\$ 112$ billion, exports about $\$ 45.5$ billion and imports about $\$ 31.63$ billion (Ondo Mañe, 2005).

Given Cameroon's geopolitical and geostrategic position in the region, the Cameroonian government authorities want to make it an emerging state by 2035. It is based on these projections that in 2006, the so-called structuring projects were launched. This includes the construction of the Kribi Agro-Industrial and Urban Port Complex on the Kribi's maritime façade, precisely in the Mboro village.

\subsection{The Kribi Industrial and Urban Port Complex (KIPC)}

The Port of Kribi aims to become a vital port and logistics platform in the Central African subregion and even in the Gulf of Guinea. In addition to the above-mentioned assets, the central positioning of this infrastructure in the Gulf of Guinea allows the harbor port to catch traffic flows from land-locked countries, with all ambition to become regional hub. This new infrastructure is in registered line with other major African ports like El Hamdania (Algeria), Cotonou (Benin), Doraleh (Djibouti), Owendo (Gabon), Boké-Dapilon (Guinea), Abidjan (Ivory Coast), Lamu (Kenya), N’Diago (Mauritania), Maputo (Mozambique), Lekki (Nigeria), Bagamoyo (Tanzania), with the peculiarity that they are mostly built under Chinese financing.

The Cameroonian government plans to transform this zone into a deep sea industrial complex, over an area of more than 26,000 hectares. It will consist of four components that will extend for approximately $30 \mathrm{~km}$ towards the South (in the direction of Campo city), namely: 
- A deep water harbor port which in future will be able to accommodate ships with more than $25 \mathrm{~m}$ draft;

- A zone for industrial and logistics activities with about twenty terminals and wharfs including mineral and hydrocarbon terminals;

- A multimode of transport corridor;

- A construction of a new modern city, of over 100,000 inhabitants.

For years, the construction of this infrastructure has received great publicity but very little has been said about the environmental impact. It is clear that such achievements cannot be without any impact on the environment. Actually, some reports already highlight pollution in the north of Kribi following the exploitation of hydrocarbons, which is a clear danger for the surrounding ecosystems as in California where Chevron's Richmond Refinery has spilled hundreds of gallons of oil into the San Francisco Bay for ages. This is the raison de être of this paper, which seeks to establish a database of pollution indicators, observe their evolution over time and suggest appropriate decisions for the preservation of the environment.

\subsection{Aims of the Study}

Like this assertion of Benoit Proudhon, we aim to understand and diagnose to better protect our environment, explore and analyze to better develop our subsoil, measure and model to better anticipate risks, innovate and develop to adapt to the world of tomorrow. In Cameroon coastal region, monitoring and environmental assessment of seawater are a great first in the country not only because it is conducted prior to the construction and pollution of the infrastructure, but is also a project that will allow an efficient monitoring of all port activities and their pollution risks in the entire port and surrounding peri-urban area in a near real time. Its main objectives are thus elucidated:

- The identification, the analysis and the interpretation of the pollution agents on the Kribi Lolabe coastline including the perimeter of the port area;

- To identify the different elements of the natural environment of the study area which are permanently exposed to the attacks related to the activities that generate polluting agent;

- Present the different actors of the environmental management of the Kribi maritime zone and foresee the measures adopted for a sustainable management of this vital and sensitive space. This, with the aim of avoiding damage to the natural environment as was the case when similar infrastructures of lesser scale were built in the country, notably in Douala and Limbe. Around the Autonomous Port of Douala, Essoumba Bata (2004) collected sediments and water samples and subjected them to physicochemical $\left(\mathrm{T}^{\circ} \mathrm{C}, \mathrm{pH}\right)$, biological (BOD5 and COD) and bacteriological analyses with conclusion that, waters of the fluvial port of Douala are urge polluted. While in Limbe, the results of the analysis of $\mathrm{pH}, \mathrm{COD}, \mathrm{BOD} 5$, hydrocarbons $(\mathrm{HC})$ and phenols were found to be high in the streams of the villages of Bota, Mokundange, Cap Limboh, and Batoke (Njimonkut, 2008). These are suspected to be the 
cause of many health problems experienced by the inhabitants of these sites.

In April 2015, the completion of the first component of the project, which was the construction of part of the deep-water harbor, motivated this study. Two major objectives were set. The first is to assess the state salubrity of the Kribi Deep-Water Harbor (KDWH) located $35 \mathrm{~km}$ south of Kribi city through the analysis of pollutant parameters and d their sources. Secondly, it is necessary to establish a baseline environmental pollution status data. On the basis of pollution evaluation parameters, in future they could be monitored by means of control via a monitoring and management system.

The implementation of this project will not only provide a typical example for further evaluation of marine pollution and environmental risk monitoring in the Kribi region but can also be used as roadmap for the evaluation and monitoring of similar projects in other regions.

\section{Regional Background}

\subsection{Location, Climatology, Flora and Fauna}

The study area is located in the southern part of Kribi, in the Ocean Department of the South region of Cameroon. It merges with the shore line from Kribi to Lolabe (Figure 1).

Kribi/Campo has an equatorial climate and is exposed to oceanic influences as well as the forest ecosystem. This area is characterized by two distinct dry seasons (November-March and July-mid-August) and two rainy seasons (April-June and mid-August-October). Average annual rainfall generally decreases with increasing distance from the coast, ranging from $2950 / \mathrm{mm} /$ year in Kribi to 2800 $\mathrm{mm}$ in Campo. The rainiest months are from August to October (Figure 2). These averages often increase to reach $27^{\circ} \mathrm{C}$ in the dry season with a maximum of $31.5 \%$ in March. The average minimal temperatures are in the region of $23.4^{\circ} \mathrm{C}$, with $32.5 \%$ as monthly maxima.

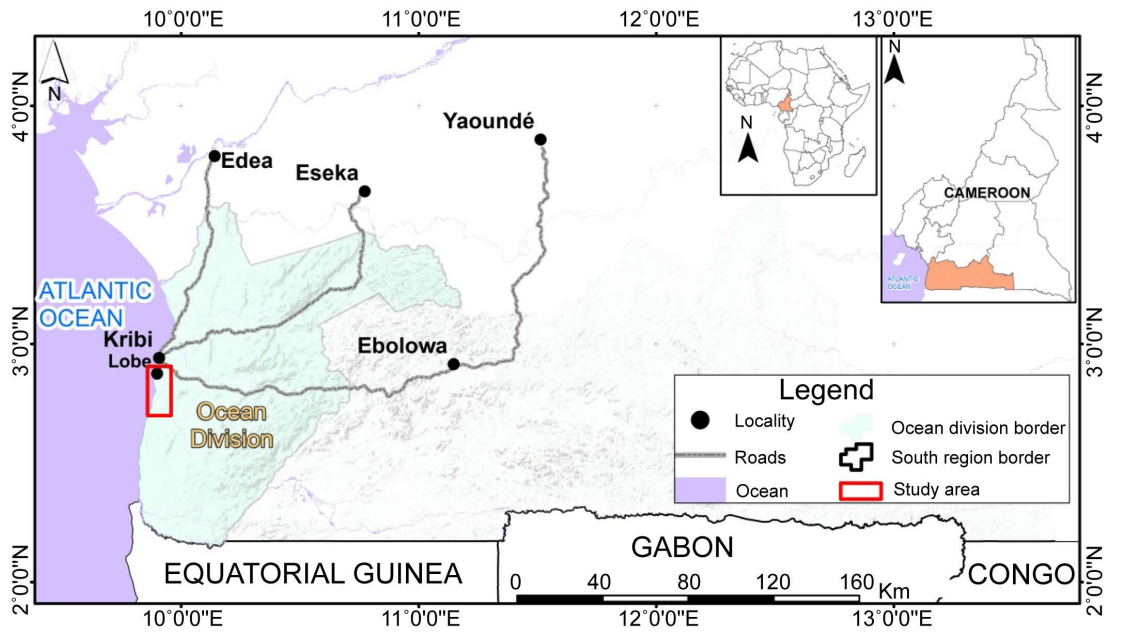

Figure 1. Location of Kribi Industrial Port Complex (KIPC) in the Cameroon's southern region. 
J. F. M. A. M. J. J. A. S. O. N. D.

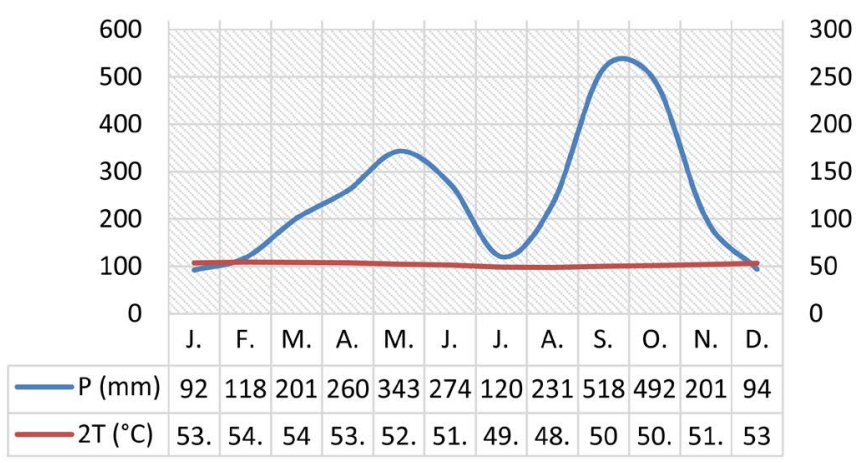

Figure 2. Ombrothermal diagram of Kribi (Master plan for the development of the southern coast of the Cameroonian littoral).

The Flora is broadly defined by large evergreen moist dense forests of the Biafrean Atlantic District (Atlas of Africa and Cameroon, 2010). Floristic analysis shows a high Shannon diversity index (5.3) indicating a rich and diverse flora composed of 83 species, 73 genera and 29 families. Among these is one endangered species (Diospyros crassiflora), two lower risk/near threatened species (Dialium bipendense, Irvingia gabonensis) and vulnerable species mostly wood with high marketing value (Afzelia bipindensis, Entandrophragma angolensis, Entandrophragma utile, Khaya ivorensis, Lovoa trichilioïdes, Pterygota macrocarpa) (Ngueguim et al., 2017).

Kribi contains a very rich biodiversity of flying, aquatic and terrestrial species of which many species in the Campo Ma'an National Park and to an extent in the Doula-Edea wildlife reserve have been listed. A previous analysis by Burke et al. (2001) revealed that $72 \%$ of the coastline can be considered as natural and $28 \%$ as altered by human activities. From a general point of view, that would be the case in the Kribi region.

\subsection{Hydrography and Hydrogeology}

Kribi has an extremely dense and dendritic hydrographic network (Figure 3), with a general East-West flow direction imposed by the western slope of the South-Cameroonian Plateau. The hydrography of the sector is that of the Lobe watershed $\left(2305 \mathrm{~km}^{2}\right)$. The only information on groundwater of the sector is from an investigation made by AES/Sonel, the former company distributing the electrical energy on the site of Mpolongwe. They revealed that groundwater can be found between 3 and $11 \mathrm{~m}$ depth. Also a second groundwater layer can be captured north of the Kribi region, and is 60 to $70 \mathrm{~m}$ deeper from the ground level.

\subsection{Geology and Pedology}

The coastal plain is the highest elevation zone (0 - $350 \mathrm{~m}$ ), (Segalen, 1967; Njike Ngaha, 1984) in this area of southern plateau of Cameroon. Small hills whose altitudes do not exceed $160 \mathrm{~m}$ are dotted in the area forming a classic profile of the 


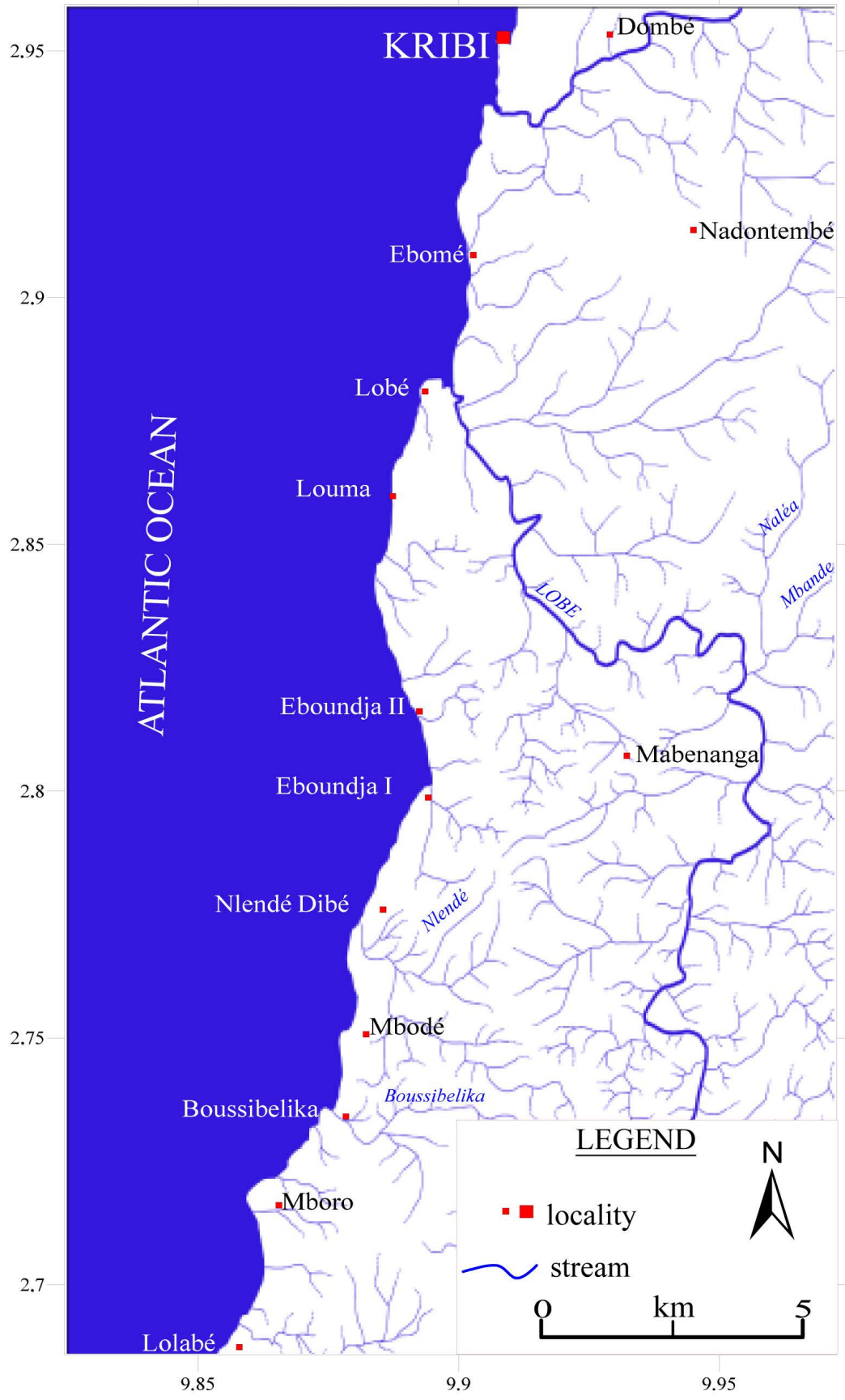

Figure 3. Hydrography of the Kribi-Lolabe area.

relief in the equatorial zone. In the area, ferrallitic red and yellow soils on interfluves and hydromorphic soils in the lowlands are distinguished, respectively (Martin, 1967; Bilong, 1988; Bekoa, 1994).

Kribi is underlain by mainly the crystalline basement of the Lower Precambrian Formations belonging to the Ntem Complex. These are foliated rocks such as pyroxene gneiss, pyroxenite and pyroxeno-amphibolite. Further south in the direction of Campo, metamorphic rocks belonging to the Nyong Unit, forming shale, micaschist and marls also outcrop. The coastal zone of the study area in- 
cludes the Kribi-Campo sub-basin which results from the opening of the South Atlantic (Ntamak-Nida et al., 2010; Kue Petou et al., 2017). Offshore, the stratigraphic sequence presents from the bottom to the top the following Formations:

- Mundeck (Apto-albian: Lower Cretaceous) consisting mainly of basal sandstones and lies directly in unconformity on the Precambrian granitic basement;

- Logbadjeck (Late Cretaceous) dominated by marine clays;

- Logbaba, N'kapa, Souellaba, Kribi and the Matanda constituting the tertiary (Eocene-Miocene) see the deposit of clay and sand.

\subsection{Socio-Environmental Aspects}

Kribi as an attractive city has a very cosmopolitan population. From indigenous or local populations to people from all over the national territory, in addition to foreigners from other African countries, Europe and Asia make up the 80,000 inhabitants in the area. This number could reach 300,000 in the next 15 years according to the regional United Nations Development Program (UNDP). This is a global trend because in $2003,41 \%$ of the world's population lived in coastal areas and mostly in developing cities (Martínez et al., 2007). The socio-economic activities that are ongoing in the area range from the primary to the tertiary sector exert serious and direct pressure on the coastal environment with the main outlet which is the ocean for their waste.

\section{Methods and Analysis}

Data were collected from published articles, online journals, social media, public and unpublished reports, and the priority was given to data from scientific articles and technical reports. These datasets were then compiled and compared them with international standard datasets. A field survey was done in 2014, four years after of the start of construction. During this survey, possible points for seawater sample collection were selected (Figure 4). The compilation of various data and their efficient reporting was facilitated by the Field Geologist application developed by the IRGM (Institute of Geological and Mining Research Cameroon).

In the laboratory, these parameters were determined using specialized techniques and equipment:

- The preliminary parameters: Suspended material or matière en suspension (MES) in French meaning. The concentration of suspended matter (SM) is obtained by filtration and weighing. A given volume of the sample is filtered through a membrane that has been steamed and weighed. Nitrate or cellulose acetate membranes with a porosity of $0.20 \mu \mathrm{m}$ are used. Once the filtration is completed, the membrane is put back in the oven and weighed again. The TSS concentration is equal to the weight of the retained material (weighing difference) on the filter relative to the volume of water and expressed in $\mathrm{mg} / \mathrm{L}$. 


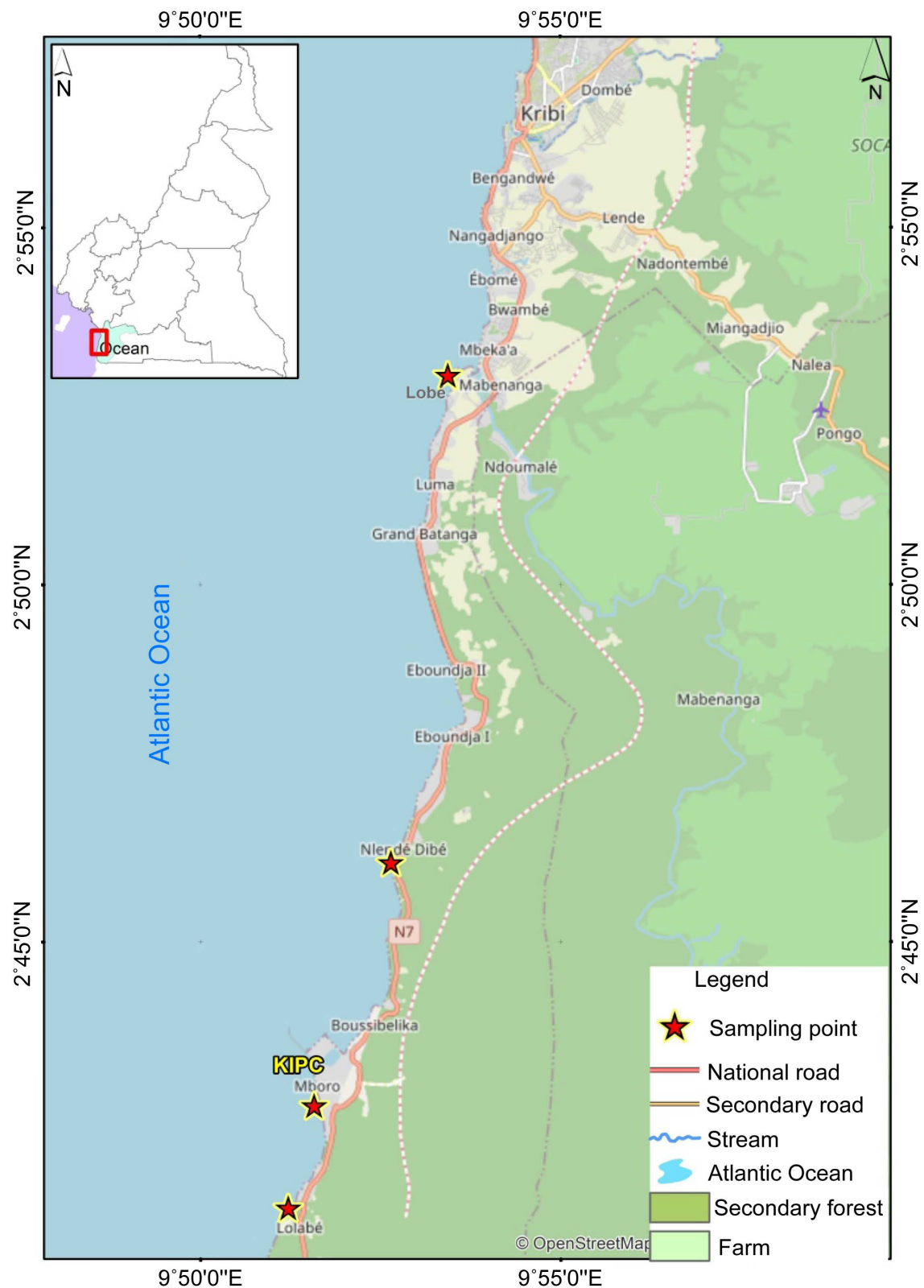

Figure 4. Sampling map.

- The physico-chemical parameter: Conductivity, $\mathrm{T}^{\circ}, \mathrm{pH}$, turbidity,

- Conductivity (C) and temperature like resistivity; conductivity is a function of temperature. The conductivity was measured with a multiparameter conductivity meter WTW $330 \mathrm{i}$ at $25^{\circ} \mathrm{C}$. It was observed that $\mathrm{C}$ increased on average by $2 \%$ per degree;

- $\mathrm{PH}$ and turbidity were determined by a pH meter (HI991002) and a turbidimeter (Orbeco-Hellige model 966), respectively and expressed in nephelometric turbidity units (NTU);

- In micro equivalent per liter $(\mu \mathrm{Eq} / \mathrm{l})$, the alkalinity determination is done by titration.

In order to determine precisely the equivalence point, a calculation program is 
used which associates the Gran curve, deduced from the variation curve of the $\mathrm{pH}$ according to the volume of acid added.

- The alkalinity of a water is actually the bicarbonate $\left(\mathrm{HCO}_{3}^{-}\right)$content of the water; its conversion is as follows:

$\mathrm{HCO}_{3}^{-}: 61 \mathrm{~g} / \mathrm{mol}$, molar mass $\mathrm{M}$ of $\mathrm{HCO}_{3}^{-}$,

Concentration $(\mathrm{mg} / \mathrm{L}) / \mathrm{M}(\mathrm{g} / \mathrm{mol})=\mathrm{x} \mathrm{mmol} / \mathrm{L}$

$\mathrm{x} \mathrm{mmol} / \mathrm{L}$ being the molar concentration of $\mathrm{HCO}_{3}^{-}$,

$1 \mathrm{mmol} / \mathrm{L}=1 \mathrm{meq} / \mathrm{L}=1000 \mu \mathrm{eq} / \mathrm{L}$;

$\mathrm{x} \mu \mathrm{eq} / \mathrm{L} \times \mathrm{M}=$ y $\mu \mathrm{g} / \mathrm{L}$.

$\mathrm{y} \mu \mathrm{g} / \mathrm{L} \div 1000=\mathrm{z} \mathrm{mg} / \mathrm{L}$, is the mass concentration of $\mathrm{HCO}_{3}^{-}$.

Along with dissolved oxygen, the preliminary and physico-chemical parame-

ters were analyzed by the Laboratoire d Analyse Géochimique de l Eau (LAGE) at IRGM (Institute of Geological and Mining Research).

- The chemical pollutants: anions and major cations,

The anions are determined either by colorimetry or by titrimetry.

- Colorimetry is done for sulfates, nitrates, nitrites, phosphates and ammonium ion.

- Titration is done for carbonates, bicarbonates and chlorides.

- Indicators of organic pollution:

- $\mathrm{NO}_{3}^{-}$.

- DO (Dissolved Oxygen), dissolved oxygen was measured with a HANNA HI9143 oximeter and determined as a percentage of saturation in a liter of sample and in $\mathrm{mg} / \mathrm{L}$. This parameter is determined from the compound oxidation equation: Compound $+\mathrm{O}_{2} \rightarrow$ simplified compound $+\mathrm{CO}_{2}+\mathrm{H}_{2} \mathrm{O}$.

- BOD5 (Biochemical Oxygen Demand over 5 days), its determination was done by the so-called "manometric" method using a Hach BOD5 apparatus, model 2173B.

- COD (Chemical Oxygen Demand), which was carried out by the method known as "reactor digestion".

- Major anions $\left(\mathrm{Cl}^{-}, \mathrm{SO}_{4}^{-}, \mathrm{PO}_{3}^{-}\right)$were measured using the colorimetry and titrimetric methods while the cations $\left(\mathrm{Ca}^{2+}, \mathrm{Mg}^{2+}, \mathrm{Na}^{+}, \mathrm{K}^{+}\right)$in the filtered water were analyzed by Atomic Absorption Spectrometry.

\section{Results}

The analysis results are recorded in a tabular form.

\subsection{Suspended Material (SM) and Physico-Chemical Parameters}

See Table 1.

\subsection{Chemical Pollutants: Anions and Major Cations}

See Table 2.

\subsection{Organic Pollution Indicators}

\section{See Table 3.}


Table 1. Preliminary and physico-chemical parameters.

\begin{tabular}{|c|c|c|c|c|c|c|}
\hline \multicolumn{2}{|c|}{ Preliminary parameters } & \multicolumn{4}{|c|}{ Sampling point } & \multirow{2}{*}{ Standard } \\
\hline Parameters & Unit & $\mathrm{P} 1$ & $\mathrm{P} 2$ & P3 & P4 & \\
\hline Suspension/MES & $\mathrm{mg} / \mathrm{L}$ & 10.00 & 36.80 & 19.20 & 12.00 & $25-50$ \\
\hline \multicolumn{7}{|c|}{ Physico-chemical parameters } \\
\hline Temperature & ${ }^{\circ} \mathrm{C}$ & 24.4 & 25.7 & 28.7 & 28.7 & $20-29$ \\
\hline $\mathrm{pH}$ & U.S.I & 7.35 & 8.15 & 7.52 & 7.93 & $6.5-8.5$ \\
\hline Conductivity & $\mathrm{mS} / \mathrm{cm}$ & 6.94 & 35.8 & 35.1 & 35.7 & \\
\hline Dissolved Sediment Rates & $\mathrm{mg} / \mathrm{L}$ & 0FL & OFL & OFL & oFL & \\
\hline Salinity & $\mathrm{g} / \mathrm{L}$ & 3.8 & 22.6 & 22.1 & 22.5 & $\leq 35$ \\
\hline Turbidity & NTU & 3.8 & 0.9 & 1.2 & 1.6 & $\leq 5$ \\
\hline Alconite & $\mu \mathrm{Eq} / \mathrm{L}$ & 308 & 1324 & 1194 & 2527 & $1934.43-2393.44$ \\
\hline $\mathrm{HCO}_{3}^{-}$ & $\mathrm{mg} / \mathrm{L}$ & 18.788 & 80.764 & 72.834 & 154.147 & $118-146$ \\
\hline
\end{tabular}

Table 2. Chemical pollution indicators.

\begin{tabular}{ccccccc}
\hline \multicolumn{2}{c}{ Chemical pollutants } & \multicolumn{5}{c}{ Sampling point } \\
Anions & Unit & $\mathrm{P} 1$ & $\mathrm{P} 2$ & $\mathrm{P} 3$ & $\mathrm{P} 4$ & Standard \\
\hline Chlorides $\left(\mathrm{Cl}^{-}\right)$ & & 2307.80 & $12,318.88$ & $12,691.10$ & $11,698.50$ & 19,354 \\
Sulphates $\left(\mathrm{SO}_{4}^{2-}\right)$ & & 0.051 & 0.035 & 0.023 & 0.037 & 2712 \\
Phosphates $\left(\mathrm{PO}_{4}^{3-}\right)$ & & 0.000 & 0.000 & 0.000 & 0.000 & 0 \\
Cations & & & & & \\
Calcium $\left(\mathrm{Ca}^{2+}\right)$ & $\mathrm{mg} / \mathrm{L}$ & & & & & \\
Magnésium $\left(\mathrm{Mg}^{2+}\right)$ & & 131.63 & 1018.41 & 993.37 & 1000.12 & 1300 \\
Sodium $\left(\mathrm{Na}^{+}\right)$ & & 537.91 & 920.20 & 859.61 & 938.16 & 10,770 \\
Potassium $\left(\mathrm{K}^{+}\right)$ & & 42.00 & 349.50 & 380.20 & 379.40 & 399 \\
\hline
\end{tabular}

Table 3. Organic pollution indicator parameters.

\begin{tabular}{|c|c|c|c|c|c|c|}
\hline \multicolumn{2}{|c|}{ Organic pollution parameters } & \multicolumn{4}{|c|}{ Sampling point } & \multirow{2}{*}{ Standard } \\
\hline Parameters & Unit & $\mathrm{P} 1$ & $\mathrm{P} 2$ & P3 & $\mathrm{P} 4$ & \\
\hline Nitrates, $\mathrm{NO}_{3}^{-}$ & $\mathrm{mg} / \mathrm{L}$ & 0.286 & 1.002 & 1.360 & 1.217 & $0-50$ \\
\hline \multirow{2}{*}{ Dissolved oxygen } & $\%$ & 72.3 & 64.8 & 63.9 & 64 & \\
\hline & $\mathrm{mg} / \mathrm{L}$ & 5.87 & 5.01 & 4.91 & 4.93 & \\
\hline BOD5 & $\mathrm{mg} / \mathrm{L}, \mathrm{O}_{2}$ dissolved & 35 & 40 & 110 & 20 & \\
\hline COD & $\mathrm{mg} / \mathrm{L}, \mathrm{O}_{2}$ dissolved & 124 & 373 & 296 & 334 & \\
\hline $\mathrm{COD} / \mathrm{BOD} 5$ & & 3.543 & 9.325 & 2.691 & 16.700 & \\
\hline MO & $\mathrm{mg} / \mathrm{L}$ & 64 & 151 & 172 & 124.67 & \\
\hline
\end{tabular}

\section{Interpretation and Discussion}

In this part, the results obtained will be compared to those of the international 
standards taken as threshold values beyond which, the space concerned can be considered polluted according to the studied parameter.

- Preliminary parameters: Suspended Material

In view of the results and in comparison with those of international standards $(25-50 \mathrm{mg} / \mathrm{L}$ ), we notice that the marine waters of the Kribi coast do not contain a sufficient quantity of suspended material.

\section{- Physico-chemical parameters:}

Temperature: The temperature of coastal rivers is roughly the same as that of the surface waters of the Kribi coast and remains below $30^{\circ} \mathrm{C}$ throughout the year. It is a biotic value allowing the development of living species. Thermal pollution of the coastal waters of Kribi is therefore excluded.

$\mathrm{PH}$ : This range is between 7.35 (P1) and 8.15 (P2), this range suggests a healthy environment $(6<\mathrm{pH}<9$, Senegalese standards) for this parameter.

Turbidity: Focusing on this parameter, we conclude that the coastal waters of Kribi are clear to fairly clear (Table 4). Because the NTU of the 04 sampling points varies from 0.9 to 3.8 (to P2 and P1 respectively). In short, pollution due to the lack of clarity of water is not sufficient.

\section{- Chemical pollution indicators}

The figures below (Figures 5-8) illustrate the major anions and cations, both anthropogenic and naturally occurring in water at the four sampling points.

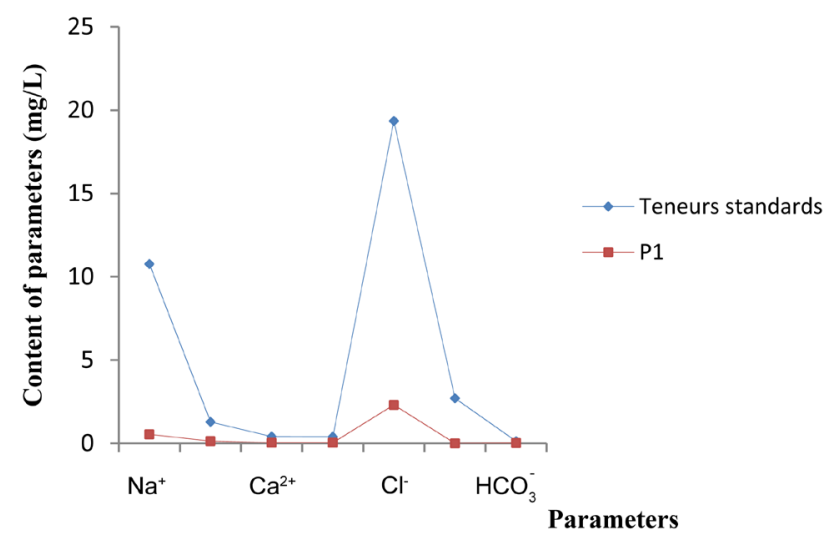

Figure 5. P1 parameter content relative to standard contents.

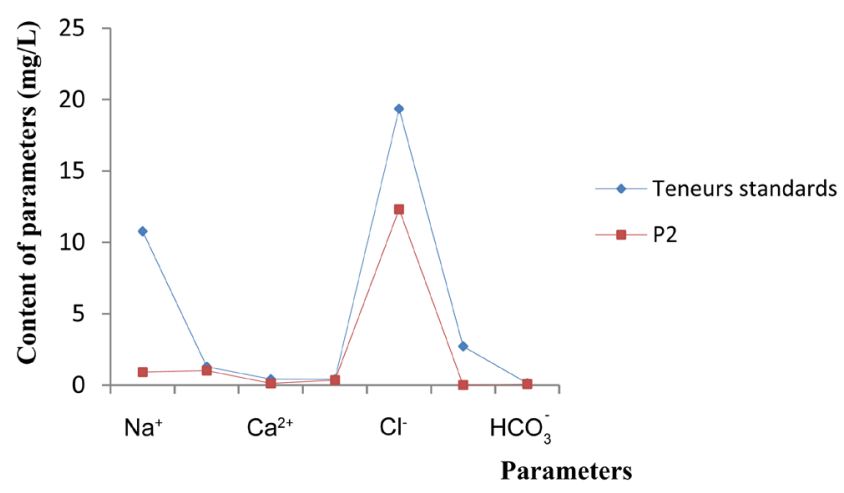

Figure 6. P2 parameter content relative to standard contents. 


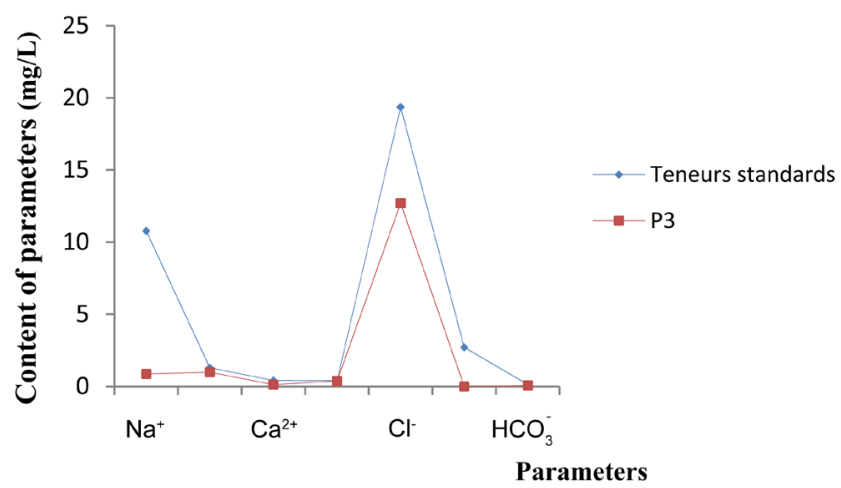

Figure 7. P3 parameter content relative to standard contents.

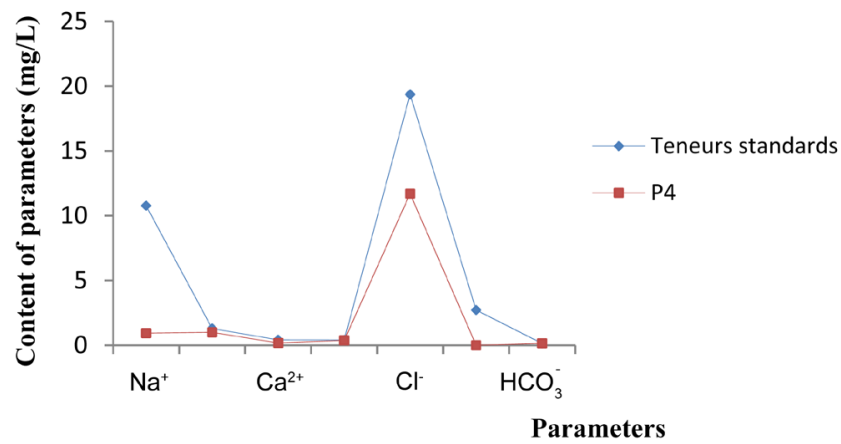

Figure 8. P4 parameter content relative to standard contents.

Table 4. Usual turbidity class (NTU, Nephelometric Turbidity Unit).

\begin{tabular}{cc}
\hline NTU $<5$ & Clear water \\
NTU $<30$ & Slightly cloudy water \\
NTU $<50$ & Murky water \\
\hline
\end{tabular}

\section{- Indicators of organic pollution}

Nitrates $\left(\mathrm{NO}_{3}^{-}\right)$: They are present at sea in favor of animal waste (native and non-native). The maximum allowable $\mathrm{NO}_{3}^{-}$concentration for drinking water and regulated by the $\mathrm{WHO}$ is set at $50 \mathrm{mg} / \mathrm{L}$; this value is 167 times greater than the value obtained at the mouth of the Lobé and 50 times greater than the marine values. The presence of $\mathrm{NO}_{3}^{-}$in the area is therefore safe.

Dissolved oxygen is a parameter that is very useful in the biological diagnosis of the marine environment, and the results obtained are similar to standards and the free oxygen content at P1 (72.3) is good. This state can be explained by the presence:

- estuarine water;

- the presence of cataracts;

- Contains fewer particles and suspended matter.

BOD5 is generally between 20 and $40 \mathrm{mg} / \mathrm{L}$ dissolved $\mathrm{O}_{2}$ on the coast. However, the values obtained show a slight contribution of the organic material (autochthonous and allochthonous) without any real sign of pollution. COD has 
high levels due to a high alkalinity of marine water. However, the ratio of COD/BOD5 in healthy streams ranges from 1.5 or 2 to 5 ; in the zone, it ranges from 2.7 (P3) to 17 (P4) which shows the biological inalterability. Despite the absence of BOD5 and COD standards for seawater, it will not be possible to accurately indicate the state of pollution. Certainly, the contents are high, but to say that the marine water has a dubious quality in these results would be somewhat exaggerated. In the same vein of exposing the limitations of this study; it is noted that the number of samples is somewhat insufficient for the systematic characterization of the state of water pollution in the port area of Kribi. To this end, it is recommended to have a tighter sampling grid of the waters to be studied. The results obtained can be compared with those obtained from similar studies conducted elsewhere in ports whose activities date back from several decades...

With regard to pollution of the water table, the risks of pollution are proven. In large African coastal cities like Abidjan, Cotonou and Lagos show a rapid evolution of chemical elements (sulphate, nitrate, chlorides) on groundwater from 2002 to 2012 (Nlend et al., 2018). This increase would be related to human activities (Abderamane, 2012). In Kribi, the activities include the agro-industry, forestry industry, oil \& gas exploration and exploitation and related development, coastal sand mining and mining (Mioumnde et al., 2019), industrial fishery, port traffic, other industries, trade, tourism and eco-tourism on a large scale. On a small scale, mostly livelihood activities such as agriculture, hunting, fishing, arts and crafts, local industry and trade, and periodic markets are practiced. In Douala, it is moderately high but in sharp decline due to intrusions of seawater into the water table (Steyl \& Dennis, 2009). This may be due to the proximity to Mount Cameroon whose sporadic shocks would have an effect on hydrogeology. The region of Kribi further south of Douala could be less impacted. Then one might believe by conjecture that the rate of chemical elements over time and population growth may be higher than those of Douala. On the quality of groundwater in Kribi, informations obtained from some well indicate high iron concentration.

\section{General Appreciation and Feasibility}

\subsection{Monitoring and Remote Sensing}

The application of remote sensing in environmental monitoring is undoubtedly inevitable. This will entail the use and observation of the changes of the pollutant parameters for a period of more than four decades, via satellite imagery on the evaluation impact on the earth's biosphere degradation. In Cameroon, numerous studies on the environment have applied these techniques, especially on the growing environmental problem of deforestation (Mertens \& Lambin, 2000; Verhegghen et al., 2016). Part of Cameroon belongs to the Congo Rainforest, the second largest continuous tropical forest in the world, where many similar studies have been done. 
In the Kribi region, a study of the surrounding biodiversity of KIPC's construction site has laid the foundation for imagery satellite monitoring (Megope Foonde, 2018). In this perspective, the possibility of a comprehensive monitoring of the environment in this region is envisaged in the next thirty years. Future work incorporating current data from this paper and future ones will focus on Landsat image from NASA-USGS. The choice is based on its higher resolution making it particularly suitable for pixel-by-pixel change detection analysis, free online availability and large historical archive (Wulder et al., 2016); Hansen and Loveland (2012). Furthermore, the use of remote sensing and high-resolution satellite image can help to survey for years the evolution of landscape and vegetation around the project area (Nilsson et al., 2015).

\subsection{Consciousness Program}

Although the indices of pollution of anthropic orders have been reported in the north of the zone five years after the start of the construction of the KDWH, the indicators of pollution currently present no anomaly. Mboro and the surrounding areas of the KIPC construction site, are housed in a relatively healthy environment. In addition, the risks of pollution are foreseen in the horizon with the completion of this megastructure and its impact on the region. Also, backed by the current scenario and the climate change prediction in the coastal environments worldwide, the Kribi region is likely to face serious environmental issues. That should be worked in advance, in order to achieve a sustainable development of the most valued rental. Therefore, a real program for Integration and Management of Coastal Cities (IMC) from Kribi to Campo should be put in place as soon as possible.

ICM is a dynamic process which aims, through a set of actions and inter-sectoral participation, to improve the quality of life of the people living in the coastal zone, and promote sustainable development by protecting ecosystems and coastal resources (Ngoran \& Xue, 2017). This type of program has been successfully applied particularly in the Philippines. Thailand fruitfully implemented ICM (Kong et al., 2015). Likewise, Japan and Korea have developed and implemented the ICM program (Liu et al., 2012). European State structures such as the Ocean Equipment and Development Mission (MEAO, French meaning) must be reformed in their action plan, while updating the master program such as the Master Plan for the Development of the Southern Coast of the Cameroonian coastline, for current and future challenges.

The setting up of a program such as the National Emergency Program against Accidental Hydrocarbon Spills (PNLDAH, French meaning) by the public authorities is salutary, it should also be a recommendation to put in place a program like a Water Management Program (WMP) to reduce the risks of anthropogenic pollution. For this purpose, a technical-physical framework including a better urbanization plan that will be rigorously and scrupulously respected should be developed. This will help to avoid the urban disorder observed around 
some national ports like Limbe and Douala. Thus, the setting up of a monitoring and observation unit for environmental issues around the project is imperative. Such a unit will facilitate the re-evaluation of data every five years, in order to highlight the evolution of the pollution parameters and their control via a system of management by geographical information system.

\section{Conclusion and Perspectives}

Cameroon is facing its emergence through so-called structuring projects including the Kribi Industrial Urban Port Complex. These projects must incorporate sustainable development policies to optimize economic growth. After the first phase of construction of the Kribi Deep Water Harbor, the purpose of this research was to assess the quality of the marine water of the area surrounding the project. The results serve to set a reference for the subsequent impact analysis. In this evaluation, the use of preliminary, physico-chemical and biological parameters was required while emphasizing the region's aquifers. From the results of analysis, it appears that:

- The physicochemical parameters in the Kribi's marine water have concentrations below (Tables 1-3) international standards. Their inferiority to international standards lies in the large part of their dilution by coastal rivers, given the imposing hydrography of southern Cameroon;

- COD is high because of the high alkalinity of marine water;

- The pollutants or parameters found in the environment have an almost natural origin base to organic matter.

The coast from Kribi to Lolabe via the Kribi Deep Water Harbor area at Mboro, would be for the time, exempt from any form of pollution due the implementation of the project. Nevertheless, there is a slight source of anthropogenic pollution, which, with the demographic rise will increase for sure. To complete this study, it would be advisable to analyze other parameters such as trace metals and hydrocarbon pollutants (polycyclic aromatic hydrocarbon (PAHs), polychlorinated biphenyls (PCBs)) in order to have a broad-spectrum view on the risks of pollution, because COD is high, and hydrocarbons will also need to be titrated in hopes of determining the source of the biological and unalterable organic matter.

In the light of combating the risks of environmental degradation and maintaining the balance of ecosystems in the area, a management and monitoring program has been proposed for the control of the parameters and pollution factors. This can be achieved through the use of remote sensing and high resolution satellite image in order to respond effectively to the aspirations of sustainable development, to draw up an adequate management model that encompasses aquifer and marine pollution control, for both the population and the Kribi Industrial Urban Port Complex. For better effectiveness with a wide spectrum of observation, we recommend similar studies in other Cameroonian ports and beyond. 


\section{Conflicts of Interest}

The authors declare no conflicts of interest regarding the publication of this paper.

\section{References}

Abderamane, H. (2012). Etude du fonctionnement hydrogéochimique du système aquifère du Chari Baguirmi (République du Tchad) (324 p). France PhD Thesis, Poitiers: Univ de Poitiers. (In French)

Atlas of Africa and Cameroon (2010). Editions du Jaguar, 82 p.

Bekoa, E. (1994). Etude pétrologique et géochimique d'une couverture pédologique en zone forestière de l'extrême Sud-Cameroun: Relation avec la dynamique du fer (187 p). Thèse Doctorat 3éme cycle, Yaoundé: Université Yaoundé I.

Bilong, P. (1988). Genése et développement des sols ferrallitiques sur syénites alcalines potassiques en milieu forestier du Centre-sud Cameroun. Comparaison avec les sols ferrallitiques développés sur roches basiques (367 p). Thèse d'état, Yaoundé: Universite Yaoundé.

Burke, L., Kura, Y., Kasem, K., Revenga, C., Spalding, M., \& McAllister, D. (2001). Coastal Ecosystems (93 p). Washington, DC: World Resources Institute.

Essoumba Bata, C. N. (2004). Etudes des pollutions et leurs impacts sur l'environnement du Port Autonome de Douala (70 p). Mémoire DEA Univ. Ydé I. (Unpublished Paper)

Hansen, M. C., \& Loveland, T. R. (2012). A Review of Large Area Monitoring of Land Cover Change Using Landsat Data. Remote Sensing of Environment, 122, 66-74. https://doi.org/10.1016/j.rse.2011.08.024

Jenkins, R., \& Edwards, C. (2006). The Economic Impacts of China and India on Sub-Saharan Africa: Trends and Prospects. Journal of Asian Economics, 17, 207-225. https://doi.org/10.1016/j.asieco.2006.02.002

Kong, H., Xue, X., Mao, Z., Ngoran, S. D., \& Yang, W. (2015). Towards Integrated Coastal Governance with Chinese Characteristics-A Preliminary Analysis of China's Coastal and Ocean Governance with Special Reference to the ICM Practice in Quanzhou. Ocean \& Coastal Management, 111, 34-49. https://doi.org/10.1016/j.ocecoaman.2015.04.008

Kue Petou, R. M., Owona Angue, M. L., Njingti, N., \& Manguelle-Dicoum, E. (2017). 3D Modelling from New and Existing Gravity Data of an Intrusive Body in the Northern Part of Kribi-Campo Sub-Basin in Cameroon. International Journal of Geosciences, 8 , 984-1003. https://doi.org/10.4236/ijg.2017.88056

Liu, W.-H., Ballinger, R. C., Jaleel, A., Wu, C.-C., \& Lin, K.-L. (2012). Comparative Analysis of Institutional and Legal Basis of Marine and Coastal Management in the East Asian Region. Ocean \& Coastal Management, 62, 43-53. https://doi.org/10.1016/j.ocecoaman.2012.01.005

Martin, D. (1967). Géomorphologie et sols ferrallitiques dans le Centre Cameroun. Cah. ORSTOM, sér. pédol, 5, 189-218.

Martínez, M. L., Intralawan, A., Vázquez, G., Pérez-Maqueo, O., Sutton, P., \& Landgrave, R. (2007). The Coasts of Our World: Ecological, Economic and Social Importance. Ecological Economics, 63, 254-272. https://doi.org/10.1016/j.ecolecon.2006.10.022

Megope Foonde, J. (2018). Change Detection: Estimating the Footprint of the Kribi Agro-Industrial and Urban Port Complex (Cameroon) from Landsat Imagery. Open Access Library Journal, 5, e4550. https://doi.org/10.4236/oalib.1104550 
Mertens, B., \& Lambin, E. F. (2000). Land-Cover-Change Trajectories in Southern Cameroon. Annals of the Association of American Geographers, 90, 467-494. https://doi.org/10.1111/0004-5608.00205

Mioumnde, A. P., Mboui, F. A. K., Kue Petou, R. M., Kabir Shola, A., Bessong, M., \& Zhang, L. (2019). Sedimentological Studies of Alluvium Deposits along Ngovayang-Bipindi of Lokoundje River, Southwestern Cameroon. International Journal of Geosciences, 10, 119-139. https://doi.org/10.4236/ijg.2019.101008

Ngoran, S. D., \& Xue, X. Z. (2017). Public Sector Governance in Cameroon: A Valuable Opportunity or Fatal Aberration from the Kribi Campo Integrated Coastal Management? Ocean \& Coastal Management, 138, 83-92. https://doi.org/10.1016/j.ocecoaman.2017.01.006

Ngueguim, J. R., Lagarde, B. J., Dicka Kwambe, E., Momo Solefack, M. C., \& Temgoua, L. F. (2017). Deforestation, Biodiversity and Biomass Losses in Kribi Deep Sea Port Area (Cameroon): Some Mitigating Measures. Journal of Ecology and the Natural Environment, 9, 87-98.

Nilsson, H., Sy, A., Ndiaye, A., Gueye, E. H. M., Cissokho, D., Kom, J., \& Fernández, M. (2015). Rapport de la Mission d'Evaluation Cameroun. MARENDA, 3. http://commons.wmu.se/marenda/3

Njike Ngaha, P. R. (1984). Contribution to the Geological, Stratigraphic and Structural Study of the Edge of the Atlantic Basin in Cameroon (131 p). 3rd Cycle Thesis, Yaounde: Fac. Sci. Univ. Yaounde.

Nlend, B., Celle-Jeanton, H., Huneau, F. Ketchemen-Tandia, B., Fantong, W. Y., Ngo Boum-Nkot, S., \& Etame, J. (2018). The Impact of Urban Development on Aquifers in Large Coastal Cities of West Africa: Present Status and Future Challenges. Land Use Policy, 75, 352-363. https://doi.org/10.1016/j.landusepol.2018.03.007

Ntamak-Nida, M. J., Bourquin, S., Makong, J. C., Baudin, F., Mpesse, J. E., Ngouem, C. I., Komguem, P. B., \& Abolo, G. M. (2010) Sedimentology and Sequence Stratigraphy from Outcrops of the Kribi-Campo Sub-Basin: Lower Mundeck Formation (Lower Cretaceous, Southern Cameroon). Journal of African Earth Sciences, 58, 1-18. https://doi.org/10.1016/j.jafrearsci.2010.01.004

Ondo Mañe, D. (2005). Emergence of the Gulf of Guinea in the Global Economy: Prospects and Challenges. International Monetary Fund, WP/05/235. https://doi.org/10.5089/9781451862546.001

Segalen, P. (1967). Soils and Geomorphology of Cameroon. Cah. ORSTOM, Série Pédolologique, 5, 187-203.

Steyl, G., \& Dennis, I. (2009). Review of Coastal-Area Aquifers in Africa. Hydrogeology Journal, 18, 217-225. https://doi.org/10.1007/s10040-009-0545-9

Verhegghen, A., Eva, H., Desclée, B., \& Achard, F. (2016). Review and Combination of Recent Remote Sensing Based Products for Forest Cover Change Assessments in Cameroon. International Forestry Review, 18, 14-25. https://doi.org/10.1505/146554816819683807

Wulder, M. A., White, J. C., Loveland, T. R., Woodcock, C. E., Belward, A. S., Cohen, W. B., Fosnight, E. A., Shaw, J., Masek, J. G., \& Roy, D. P. (2016). The Global Landsat Archive: Status, Consolidation, and Direction. Remote Sensing of Environment, 185, 271-283. https://doi.org/10.1016/j.rse.2015.11.032 